\title{
The divisiveness of Chinese identities in Singapore
}

\author{
Ashton $\mathrm{Ng}^{1}$ (i)
}

Received: 16 February 2020 / Revised: 2 November 2021 / Accepted: 3 November 2021 / Published online: 24 November 2021

(C) The Author(s) 2021

\begin{abstract}
In July 2019, the Jamestown Foundation, an American think tank, published a report accusing China of imposing a Chinese identity onto Singapore through propaganda and influence operations. In this article, I argue that the Jamestown report is factually inaccurate and is itself an influence operation aimed at engendering distrust towards China. The re-discovery of a Chinese cultural identity by some Chinese Singaporeans-from Lee Kuan Yew to Nathan Hartono-is fuelled not by China's clandestine influence operations, but by an intrinsic desire to mend ruptures in one's cultural heritage. Historically, the Chinese in Singapore have discarded or re-adopted their Chinese cultural identities depending on the degree to which contact is kept with China. When contact with China diminishes, successive generations of Singapore Chinese inevitably cease to identify China as a cultural motherland. When contact with China resumes, the Chinese in Singapore have frequently become divided, split into those who culturally identify as Chinese and those who do not. Since the 1978 reform and opening-up of China, the restoration of contact between China and Singapore have led to a rekindling of interest amongst Chinese Singaporeans in their cultural identities. This rekindling yields three major consequences. Firstly, Chinese Singaporeans may become further divided in terms of their cultural identity, with de-Sinicised, monolingual English speakers on one extreme and re-Sinicised, cultural Chinese on the other. Secondly, successive generations of re-Sinicised Singaporeans may grow up imbibing China's cultural exports, thereby becoming less distinct from their mainland Chinese counterparts. Thirdly, Singapore's government will remain incentivised to continually emphasise the distinctness of the Chinese Singaporean identity from Chinese elsewhere.
\end{abstract}

Ashton $\mathrm{Ng}$

ajkn2@cam.ac.uk

1 Faculty of Asian and Middle Eastern Studies, University of Cambridge, Cambridge, UK 
Keywords Chinese-Singaporean identity $\cdot$ Singapore $\cdot$ China $\cdot$ De-Sinicisation $\cdot$ Re-Sinicisation

\section{Introduction}

Accompanying China's rise is Western paranoia of Chinese influence worldwide (Tan 2017). In July 2019, The Jamestown Foundation, an American think tank, published a report accusing China of "using cultural organisations, clan associations, business associations, and youth programs to engage in influence operations in Singapore," in order to "impose a Chinese identity on Singapore" (Hsiao 2019). The report's factual accuracy was widely criticised by Singaporean business and clan association leaders ( $\mathrm{Ng}$ 2019c). The Chinese Embassy in Singapore, too, called the allegations "groundless and distorted from truth" (Xinhua 2019).

Historically, the Chinese in Singapore have discarded or re-adopted their Chinese cultural identities depending on the degree to which they kept contact with China. When contact with China diminishes, successive generations of Singapore Chinese inevitably cease to identify China as a cultural motherland. When contact with China resumes, the Chinese in Singapore have frequently become divided, split into those who culturally identify as Chinese and those who do not. Since the 1978 reform and opening-up of China, the re-establishment of contact between China and Singapore have led to a rekindling of interest amongst Chinese Singaporeans in their cultural identities. ${ }^{1}$ This rekindling is partly fuelled by the "desire to reconnect with [one's] historical past after this connection had been ruptured both by colonial rule and by the subsequent domination of the globe by a Western Weltanschauung" (Mahbubani 2009, p. 38). The Jamestown report ignores this intrinsic desire, and instead promotes an American-centric world view in which America's influence on the world stage is unquestioned whereas China's influence on the world stage is propagandistic.

The rekindling of a Chinese cultural identity amongst Chinese Singaporeans brings three major consequences. Firstly, ethnic Chinese Singaporeans may become further divided into those who culturally identify as Chinese, and those who do not. Secondly, future generations of re-Sinicised Chinese Singaporeans and their mainland Chinese counterparts may grow up imbibing similar cultural content, and thus become less distinct from each other. Thirdly, the Singapore government will remain motivated to continually emphasise the distinctness of the Chinese Singaporean identity "from Chinese communities elsewhere," as Singaporean Prime Minister Lee

\footnotetext{
${ }^{1}$ For examples of vigorous discussions on the Chinese Singaporean identity, see these articles published in The Straits Times, Singapore's most widely read newspaper: "National Day Rally 2019: How the Chinese Singaporean identity has evolved in 200 years" (Lai 2019), "The Chinese Singaporean Identity: A Complex, Ever Changing Relationship" (Yuen and Ng 2018a, b); "Being Chinese in Multiracial Singapore: A Framework to Check One's Ignorance" (Yuen and Ng 2018a); "An Evolving Singapore Chinese identity: Journey to the West-and now, the East (Yuen 2018a); "3 Ways in which the Chinese Singaporean Identity is Evolving" (Yuen 2018b); and "Panel on What Makes a Chinese Singaporean" (Straits Times 2018).
} 
Hsien Loong (2019a) had done in his 2019 Chinese New Year address and other speeches.

\section{The myth of malignant Chinese influence}

The Jamestown Foundation report, titled "A Preliminary Survey of CCP Influence Operations in Singapore," boldly claimed that "a statement commonly heard by Singaporeans from citizens of the PRC is: 'Singapore is a Chinese country that must cleave to Chinese interests"' (Hsiao 2019). The Jamestown report quoted this statement out-of-context from a 2016 Straits Times article (Jayakumar 2016), which in no way asserted that Chinese nationals told this frequently to Singaporeans.

Rather, this statement reflects only a strategic attitude amongst some Chinese diplomats towards Singapore, and ignores the fact that many Chinese elites view Singapore as an independent country that is entitled to pursue its own interests even when they clash with China's (Zhang 2017). Responding to the Jamestown report, the Chinese Embassy in Singapore promptly asserted, "We respect Singapore as a multi-cultural and multi-religious state" (Xinhua 2019).

The Jamestown report further asserted without evidence that

Clan and surname associations are important links through which the PRC conducts outreach: through cultural exchanges to revolutionary history sites in China, concerts for singing communist songs, "birthright" village/home visits, and so forth. These exchanges are endorsed by local offices operated by CCP united front organisations (Hsiao 2019).

The above claim was accompanied by a footnote, stating "Author's interviews in Singapore." These interviews, however, are unpublished. Their contents, as well as the identity of the interviewees, remain the author's private revelations. The president of the Singapore Federation of Chinese Clan Associations (SFCCA), Tan Aik Hock, affirmed that China has not conducted outreach through Singaporean clan associations, and that the local clan associations would, "through continually strengthening the consciousness of being Singaporean, ensure that they are not influenced by such messages" from China ( $\mathrm{Ng} 2019 \mathrm{c})$.

The Jamestown report deliberately confused the past and present roles of Singaporean clan associations. While clan associations were, historically, contact points with ancestral hometowns back in China, this traditional function became drastically diminished after Singapore gained independence in 1965. New generations of bornand-bred Chinese Singaporeans "had less affinity to the 'home' villages and provinces represented by the geography-based clans," and clan associations were soon perceived to have "lost their relevance in modern Singapore" (Pang 2015, p. 31). A basic understanding of the modern role of Chinese clans in Singapore would reveal the Jamestown report's claims as spurious.

On December 2, 1984, a one-day forum titled "How Singapore's clan associations can play a more useful role in the new era" was attended by 665 representatives from 185 clan associations. There, then-Minister without Portfolio, Ong Teng 
Cheong, urged the associations to rejuvenate themselves by "attracting younger members" and introducing "new activities that resonate with the new interests of the young." The forum's Chairman, Wee Cho Yaw, warned that clan associations faced oblivion unless they "found new roles in the new era" (Pang 2015, p. 33). Henceforth, the clan associations adopted a local, domestic focus, attracting younger members through organizing Chinese cultural performances, raising Chinese language standards, and helping less-privileged Singaporeans (Pang 2015, pp. 38-42), none of which have any connection to the Chinese Communist Party. As articulated in 2015 by then-president of the SFCCA, Chua Thian Poh, "In the next 50 years we need to evolve our own Singapore values, art forms and cultural expressions" (Pang 2015, p. 45).

The Jamestown report alleged that "the PRC exerts leverage over Singapore businessmen." It provided two examples that supposedly "demonstrate how business associations have lobbied the Singapore government on behalf of pro-PRC positions" (Hsiao 2019).

Firstly, the report claimed without evidence that, in 2004, Singapore's business community supposedly "exerted immense pressure on the Singaporean government when Prime Minister-elect Lee Hsien Loong made a 'private and unofficial' visit to Taiwan" (Hsiao 2019). The report also specified the "Singapore Chinese Chamber of Commerce" as an example of Singapore's business associations that "act as the most powerful lobby for Chinese interests." Responding to the Jamestown report, the president of the Singapore Chinese Chamber of Commerce \& Industry, Roland $\mathrm{Ng}$, assured that local Chinese business associations would not have gotten involved when Singapore-China relations soured (Straits Times 2019).

Secondly, the report stated that, when nine Singaporean military vehicles-used for training in Taiwan-were seized in Hong Kong from December 2016 to January 2017, "Singaporean Chinese businessmen, who held ties with government officials through grassroots associations and other channels, reportedly provided 'feedback' to the government to avoid stirring up trouble with China by continuing to train in Taiwan" (Hsiao 2019). The report cited two South China Morning Post articles (Chan 2016; Jaipragas 2016), neither of which contained any such information.

The Jamestown report pointed out that Singapore's largest Chinese-language newspaper, Lianhe Zaobao, attracts over five million daily page views in China. On this basis alone, the report mused that, "given the economic dependency between local Chinese-language media companies and the PRC market, this raises questions as to whether local outlets (such as Zaobao) are selling news to Singapore, or selling news to markets in the PRC - and whether they might self-censor as a result" (Hsiao 2019).

The above accusation reveals a complete unawareness of Zaobao's business moat: the ability to report objectively and credibly on China and Asia. As Singaporean Prime Minister Lee Hsien Loong pointed out at Lianhe Zaobao's 95th anniversary dinner on September 6, 2018, "If Zaobao is the same as the many media outlets in Greater China, your readers will not see value in reading your stories." The Jamestown report is, in effect, suggesting that Zaobao might abandon its own lifeblood, without providing a credible reason why it would do so. Responding to the report, the editor of Lianhe Zaobao, Goh Sin Teck, acknowledged that China's 
market is important to Zaobao, "But what to report, and how to report it-our editorial department bases that on professional news judgment. In fact, accurate, objective and neutral reports and commentaries are how Zaobao provides value" (Ng 2019c).

It is difficult to imagine the Jamestown report labelling comparable American cultural, business, and media presence in Singapore as "propaganda" and "influence operations". Ironically, the report itself exemplifies an American influence operation aimed at inciting distrust towards China. To understand how China's contemporary culture can influence the cultural identities of Chinese Singaporeans, it is essential to trace the historical development of the Chinese Singaporean identity.

\section{Chinese identities in Singapore}

Writing on the Singaporean identity, former Singaporean ambassador-at-large Kishore Mahbubani (2015, p. 246) cites the adage that "home is where the heart is" and points out that the heart is "a repository of childhood dreams, memories and sentiments." One's cultural identity is heavily influenced by the place where one's memories were formed. Historically, Singapore-born Chinese did have starkly different cultural identities from first-generation immigrants from China.

Even amongst first-generation immigrants, there remained the question of whether a "national" Chinese identity existed. As the historian John Curtis Perry (2017, p. 18) points out, the early Chinese immigrants to Singapore were deeply divided into geographical subgroups that spoke mutually unintelligible dialects, "so different as to be separate languages". Their loyalties were devoted to their families and clans back home in China-and their ancestors whom they venerated-but not to the Chinese nation as a whole. Naturally, these early immigrants segregated themselves into different living areas based on the dialects they spoke, and the different groups remained isolated from one another (Leong 2015, p. 132). Although the Chinese shared a common written script-which they pronounced in their own dialects - only a tiny minority could read.

It was only until the 1870 s when some of the Chinese in Singapore began to identify themselves as citizens of the Chinese nation. As the historian Wang Gungwu (2018, p. 103) points out, the establishment of a Qing Empire consulate in Singapore in 1877 gave the Chinese there an officially recognized identity: huaqiao, meaning "citizens or nationals temporarily living abroad." During this time period, the modern concept of a nation- "the idea that everyone should belong to some nation or another"- swept across Singapore and its surrounding region.

Even after a national Chinese identity came into existence, there remained, amongst first-generation immigrants, the question of which "China" they identified with. For those who came to Singapore towards the end of the nineteenth century, some were loyalists to the declining Qing dynasty (1644-1911), while the majority were anti-Manchu and supported Sun Yat-sen's (1866-1925) revolution to topple the Qing empire (Leong 2015, p. 136).

There still remained the question of whether first-generation immigrants identified China as their homeland. For those who came to Singapore in the early decades 
of the twentieth century, some were communists who wanted to see a communist takeover of China. When Mao Zedong (1893-1976) proclaimed on 1 October 1949 the founding of the communist Chinese nation, "many Singaporeans proudly identified with China" (Perry 2017, p. 149). For the majority, however,

the war and the Chinese Revolution following it had thinned traditional ties with China; some Singaporeans sympathized with the losers in that upheaval and people were no longer able to travel to China or as easily send money back home. The new politics disrupted traditional patterns of immigration too and China had already officially curtailed it in the 1930s. The influx of single males stopped; society grew more stable as it became more family-oriented. More Chinese began to identify themselves as Singaporeans rather than simply sojourners. (Perry 2017, pp. 153, 154)

The conclusion that we can draw thus far is that there is no single Chinese cultural identity that transcends time. Instead, Chinese cultural identities vary greatly across time and also between individuals from the same time period. Additionally, when new cultural identities arose amongst the Chinese in Singapore, such incidents have often proved divisive, as not every individual in the community will accept that new identity.

\section{First wave de-Sinicisation: from Chinese to Malayan}

For example, early Chinese immigrants to Malaya (present-day Singapore and Malaya) often intermarried with local Malay women, giving rise to new ChineseMalay fusion cultures and creoles:

In the vast majority of cases, the connection with China was sooner or later severed. For all practical purposes these locally-born Chinese became the natives of the Malayan States, having lost touch with China in every respect, except that they continued to uphold Chinese customs, and to practise, in variously modified forms, the social and religious practices of their forefathers (Lim 1917, pp. 876-877).

These Malayan Chinese became de-Sinicised, that is, they ceased to identify China as their cultural motherland. Their children, who are of mixed Chinese-Malay heritage, "spoke a new patois of Chinese in each locality, with a liberal admixture of Malay words peculiar to each Malayan region." In some communities, the use of Chinese was "entirely dropped" (Lim 1917, p. 876). These hybrid Chinese-Malay cultures resembled the local Malay culture and yet remained "distinctive from it, preserving something of their 'Chineseness' in the mixture” (Perry 2017, p. 51).

However, not all Chinese immigrants acculturated to Malayan customs:

Those who stayed often intermarried with local people. But many did not. The unassimilated ones governed themselves without supervision or protection from the home country, living in their own quarter in distinctive brick houses, keeping their own customs, enjoying their own foods, wearing their traditional 
cotton trousers and short jackets, burning incense to their own deities in their own temples... (Perry 2017, p. 17)

In the history of the Chinese in Malaya, the formation of the hybrid Malayan Chinese identity marked the first major wave of de-Sinicisation (Ng 2019a, p. 181). The introduction of this new identity divided the Malayan Chinese into (1) those who maintained thin cultural ties to China and adopted Malayan identities, and (2) those who maintained strong connections with their hometowns in China and retained Chinese cultural identities.

In the twentieth century, Chinese immigrants often ridiculed the Malayan Chinese with the term "OCBC" (Orang Cina Bukan Cina, meaning "Chinese yet not Chinese"), perpetuating the stereotype that the Malayan Chinese have "forgotten one's ancestral roots." In actuality, the Malayan Chinese had preserved several elements of traditional Chinese culture, such as marital, funerary, and festive rites, better than the newcomers (Ng 2019b, p. 263).

\section{First wave re-Sinicisation: from Malayan to Chinese}

Another divisive shift in group identity occurred with the Republic of China's founding in 1912, whereupon it launched a massive campaign to encourage nationalistic sentiments, including amongst the overseas Chinese. The central message was that "the sacred land of China was being cut up and the country dismembered," and that "the Chinese race" (Zhonghua minzu)—newly defined as the "Five Ethnicities" (Han, Manchu, Mongol, Hui, and Tibetan)—-had to unite to defend it (Wang 2018, p. 104). Many new immigrants from China brought these ideas with them to Singapore.

The Singapore-born Chinese were divided: some de-Sinicised Chinese developed nationalistic feelings towards China and "began to learn [Mandarin], the national language, and studied things Chinese to affirm their Chinese origins" (Wang 2018, p. 105). In other words, they became re-Sinicised. Others, especially those who attended British schools, swore allegiance to the British Empire and "[supported] Empire war efforts from the Boer War to two World Wars" (Wang 2018, p. 104). Popularly known as the "King's Chinese" (Lee 1998, p. 86), they thrived as middlemen "with their knowledge of English and their ability to connect with other Asians" (Perry 2017, p. 56). Between these two extremes were a complex spectrum of Chinese identities. In the history of the Singapore Chinese, the rise of patriotism towards the Republic of China marked the first major wave of Re-Sinicisation (Ng 2019a, p. 181).

Within this spectrum of Chinese identities were a group of Singapore-born Chinese who had no loyalty to China but felt a deep desire to reconnect with their Chinese heritage. Lee Kuan Yew, for example, recounted his experiences in late-1940s England:

My wife Kwa Geok Choo and I were both educated in English-medium schools. While studying in England, we became conscious of how deculturalised we were whenever we met students from China. We were like hundreds of 
Raffles College graduates, not well-tutored in their own Asian cultures, yet not part of British culture either. We were lost between two cultures. I felt separated from the mass of ordinary Chinese who spoke dialects and Mandarin. Choo and I decided we should not let our children end up the same way, Chinese by ethnicity yet alienated from their Chinese heritage. So we vowed very early on to send them to Chinese-medium schools. We wanted them to have the self-confidence and self-respect knowing their Chinese roots. (Lee 2011b, p. 34)

Lee Kuan Yew (2011b, p. 34) had great pity for the Chinese from the West Indies, who "spoke in singsong West Indian 'English' and absolutely no Chinese." Lee's herculean efforts to learn Chinese led some to call him a "born-again Chinese," to which he responded: "If this is the case, my rebirth must have taken place in the late 1940s, during my time in England. People there saw me as a Chinese, and so I became a Chinese." (Lee 2011b, pp. 32-34).

Evidently, a Chinese cultural identity need not have anything to do with political loyalty to China. In fact, when Lee Kuan Yew governed Singapore, he "literally took charge of the Ministry of Education to oversee the implementation of the bilingual education policy" (Reimers 2017, p. vi), championing the need for Chinese Singaporeans to master the Chinese language. From 1979 onwards, all ethnically Chinese Singaporean students had to study Mandarin as a second language in secondary school, and from 1981 onwards they needed a minimum grade of D7 (a low pass) in Mandarin for admission to pre-university (Lee 2011b, p. 67). Defending his bilingual policy, Lee $(2011$ b, p. 70) wrote:

Because I believe language transmits values... The Confucianist values of loyalty, honour, discipline, filial piety, emphasis on family, respect for authorityall vital for nation-building and for cultivated citizens with honourable personal attributes. These values will provide cultural ballast to our people as we adjust to a fast-changing world. Mastering both English and Chinese requires tremendous effort. But the effort has to be made, if we are to survive as a distinctive society worth preserving. If we do not, we will become deculturalised and pseudo-Western people.

\section{Second wave de-Sinicisation: from Chinese to Singaporean}

In the 1930s, China officially curtailed immigration to and from Singapore. Subsequently, "the influx of single males stopped; society grew more stable as it became more family-oriented" (Perry 2017, p. 154). New generations of Singapore-born Chinese, who could no longer travel to China or as easily remit money home, began to identify themselves as natives of Singapore. This new identity divided the Singapore Chinese community into (1) those who identified themselves as Chinese nationals and (2) those who did not.

The Japanese occupation of Singapore from February 1942 to September 1945 "made Singaporeans painfully aware that establishing an independent sovereign state was the only way to prevent control by foreign forces" (Kwa and Kua 2019, p. 
xxvi). The British failure to defend Singapore during the war-having surrendered one week after the Japanese invasion-had destroyed the legitimacy of British colonial rule. In post-WWII Singapore,

most people could now see a post-imperial world of independent states. This placed national identity above all others. The former colonies were ready to start afresh without Europeans in charge. Among Chinese, the numbers of local-born had caught up with those born in China. They looked for new identities and asked what they should now be loyal to. Could they be loyal to a new country and still retain a Chinese identity? (Wang 2018, p. 105)

Those who continued identifying themselves as Chinese nationals were mostly firstgeneration immigrants whose childhood memories were formed in China and whose feelings of patriotism were aroused. However, their numbers quickly became surpassed by Singapore-born Chinese. In 1921, first-generation immigrants constituted $76.4 \%$ of the Chinese in Singapore, but this figure had dropped to $64.2 \%$ in 1931 , and then to $42.3 \%$ in 1947 (Saw 1999, p. 33).

One example of a first-generation immigrant is my maternal aunt's mother-inlaw. She was born in Tangshan, China in 1934 and sailed to Singapore in 1946. She passed away in 2017. In her final years, she had senile dementia and could no longer recognise her children and grandchildren, but remembered with great clarity that Tangshan was her home. She was determined to return. Twice she sneaked away from her flat in Singapore and, shouldering the same carrying pole that she brought to Singapore over 70 years ago, asked members of the public for directions to "the port" (which no longer exists). On both occasions, passers-by saw the information tag around her neck and phoned her caretaker, who came to escort the old lady home.

Another example of a first-generation immigrant is my paternal grandfather, who was born in Fujian, China in 1922 and came to Singapore in 1933. He forbade his children from saying "go to China," insisting instead that they were to say "return to China," despite the fact that his children had then never been to China. He also repeatedly painted a romanticised picture of China, telling his children that China was a great nation. He believed in "the mythology that a Chinese is always a Chinese and can never be loyal to any country but China" (Wang 2018, p. 18). All three of his children, however, having been born and raised in Singapore, could not relate to his nostalgic sentiments, and identified themselves as citizens of Singapore and not China.

After the People's Republic of China was established in 1949, Singapore's colonial government severely restricted visits to China and barred mainland Chinese immigrants from coming. The Singapore Chinese generally "did not have confidence in China's new regime and going back to their hometowns meant a road without return." They were thus motivated to "take root" locally, shifting their allegiance from China to Singapore (Kwa and Kua 2019, p. xxvi). By the 1950s, the majority of the Chinese in Singapore were local-born and

understood that Singapore was not China and could not ever claim to be part of China. They were content to live and work in a plural society and were ready 
to go on doing so. In that way, their cultural identity could be preserved and their children could share their loyalty to what they valued as intrinsically Chinese (Wang 2018, p. 108).

Like the early Chinese immigrants who acquired Chinese-Malay creoles, identified themselves as natives of Malaya, and severed their ties with China, many Chinese Singaporeans today speak creole English as their first language, identify themselves as "Singaporean" instead of "Chinese" (Lim and Mathews 2017), and perceive China to be a foreign country.

Accompanying the "Singaporeanisation" of the Singapore Chinese was the gradual displacement of the Chinese language by English. This deeply divided the Singapore Chinese into two cultural groups: (1) English-speaking and (2) Chinese-speaking. Amongst the English-speaking are numerous Chinese who remained "mentally colonised" (Mahbubani 2009, p. 27). These Chinese Singaporeans "scoffed at Mandarin as a lesser language, and insisted that being unable to speak it spelt no disadvantage" (Lee 2011b, p. 161). As the Singaporean journalist Richard Lim (2011, p. 311), who went to English-medium primary and secondary schools from the mid1950 s to the late 1960 s, recounted:

English seems an easier language to learn, although I am a Chinese. When I joined the market in the late 1960s, the English-educated had an easier time finding work and were better paid than the Chinese-educated. There was an obvious divide between the two groups, who rarely mixed.... China was seen as a backward country and many of us among the English-educated tended to look down on those who went to Chinese-medium schools.... Those classmates of mine who failed in [Chinese] did not think it was something to be ashamed of. Some were even proud of it.

When the Speak Mandarin Campaign was launched in 1979 to promote a common Chinese language variant amongst Chinese Singaporeans, many English-speaking Chinese "simply did not want to participate in the campaign" (Lee 2011b, p. 161).

English steadily displaced Mandarin and dialects as a lingua franca among young Chinese Singaporeans. In 1989, less than 25 percent of Chinese Singaporean students entering primary school spoke English at home, with the majority coming from Mandarin- or dialect-speaking homes. This figure rose to 50 percent in 1999 , and 60 percent in 2012. To some of these students, "learning Chinese when they start schooling is akin to learning a foreign language" (Lee 2011b, p. 183).

\section{Second wave re-Sinicisation: from dialects to Mandarin}

On 7 September 1979, Singapore launched the Speak Mandarin Campaign, which aimed to "get all the young people — students and recent graduates — to give up dialects in five years" (Lee 2011b, pp. 152, 153). Accompanying the campaign was a total ban on dialects in all forms of media (Lee 2011b, p. 156). From 1980 to 1989, "students from mainly dialect-speaking families dropped from 64 per cent to 7 per cent" (Lee 2011b, p. 157). The campaign achieved great success in promoting 
Mandarin as a common language amongst Chinese Singaporeans, but divided Chinese Singaporeans into (1) older dialect-speakers who could not pick up Mandarin easily, and (2) Mandarin speakers who could not speak Chinese dialects. The result is that many Chinese Singaporeans today are unable to communicate with their grandparents (Johnson 2017).

Second Wave Re-Sinicisation was a government-led effort to keep Chinese Singaporeans up-to-date with developments in China. The opening up of China from December 1978 onwards resulted in a sustained influx of new immigrants from China to Singapore (Zhou 2015, p. 150). Lee Kuan Yew "sought to tap the presence of Chinese immigrants in Singapore to boost [Singapore's] Chinese-speaking environment," because he "always believed that it is important for Singaporeans to speak the standard Mandarin used... in China, not some adulterated version we concoct on our own. Language is after all for communication in a globalised world." Lee opined that new immigrants from China who work in Singapore's "broadcast and print media, in TV, radio and newspapers" can help ensure that the Mandarin used there is the standard Mandarin used in China. New immigrants who accompany their school-going children can also "become teachers and assistants in the local kindergartens" (Lee 2011b, p. 221).

Singapore also sought to replenish its ethnic Chinese population-who "have the lowest birth rates amongst all the races in Singapore"- through welcoming Chinese immigrants. Lee Kuan Yew wrote that "as long as we continue to control the inflow of new immigrants and foreign workers, the local-born Chinese and Malaysian Chinese will significantly outnumber those from China. They will not change our culture and social norms." Lee opined that Chinese immigrants who acquire citizenship or permanent residency often become "Singaporeanised in the way they think and act," and that "their children will grow up no different from other Singaporean children as they go to our schools" (Lee 2011b, p. 220).

The result was an ethnic Chinese community in Singapore that is deeply divided into new immigrants and the local born. Socio-geographical disparities, plus the perception of new Chinese immigrants as competitors, caused resentment among both sides, who "often voice their grievances and difficulties with sarcasm and disdain for the other group" (Zhou 2015, p. 154). In the 2002 national Primary School Leaving Examinations, six out of the top 17 scorers were China-born, sending "chills down the spines of many [Singapore] parents" (Huang 2019, p. 831).

The animosity towards new Chinese immigrants reached such heights that thenPrime Minister Goh Chok Tong saw a need to admonish it in his National Day Rally Speech on August 19, 2001. Goh quoted a newspaper letter from some young Chinese Singaporeans, who wrote:

We do not feel any affinity to the Chinese people. ... The cheena ${ }^{2}$ people are sucking away all the foreign investments and along with them, our jobs. ... The cheena people working in Singapore are really such a crude lot."

\footnotetext{
${ }^{2}$ Derogatory Singlish slang referring to new Chinese immigrants.
} 
Speaking to the nation, the Prime Minister rebuked: "Chinese are called 'Orang Cina' in Malay. If we are not Cina, what are we? Angmoh?"

\section{Third wave re-Sinicisation: China's cultural influence in Singapore}

In Singapore today, the rising prominence of China's popular culture creates a possibility of a third major wave of re-Sinicisation of some Chinese Singaporeans. This depends on whether future generations of Singaporeans and mainland Chinese grow up imbibing similar cultural content—-such as television, music, and social mediawhich conveys values that shape the zeitgeist of a generation.

Previous waves of de-Sinicisation and re-Sinicisation were fuelled by cultural contact with China through immigration. In the age of the internet and social media, one does not have to physically visit China to be immersed in China's cultural sphere. Numerous Chinese television blockbusters - such as the dating game show If You Are the One, television drama The Story of Yanxi Palace (2019), and singing competition Sing! China - attract by far the greatest interest in Singapore than anywhere outside mainland China, as measured by Google Trends. Newly released pop songs from China are popularised by high-profile singing competitions that draw significant viewership in Singapore, such as The Voice of China and I Am a Singer. Mainland Chinese food have rapidly become a common sight in Singapore, with mala hot pot stalls opening in most food centres. All these are a sea change from just a decade ago, when it was still common for mainland Chinese culture to be derided as backward. Given these signs, some young Chinese Singaporeans and their mainland Chinese counterparts may grow up exposed to similar cultural content, and thus become culturally less distinct from each other.

Since at least the 1950s, Chinese Singaporeans have been deeply divided into two cultural subgroups: English-speaking and Chinese-speaking. Third Wave Re-Sincisation would likely result in further dividing Chinese Singaporeans into (1) those who culturally identify themselves as Chinese, and (2) those who do not.

Examples of the former include the Singaporean singer Nathan Hartono, a former Mandarin-spurning ethnic Chinese turned Chinese language ambassador after going to China to compete in Sing! China 2016, a blockbuster singing contest widely watched in Singapore (Lim 2017). Examples of the latter include Singaporean trading representative Geraldine Lee who, in her memoir "My 10-Year Nightmare" (2011a, p. 299), described learning Mandarin as "pure torture" and "a waste of time and resources" for both herself and her monolingual children:

At the height of the "Speak Mandarin" campaign, I was taunted as a "mono" or a "banana" (yellow on the outside and white on the inside). All this made me all the more resistant to picking up Mandarin. I hated the way it was rammed down my throat and how I was made to feel inferior because I didn't speak Mandarin. In working life, fortunately, Mandarin was not a requirement.

${ }^{3}$ Singaporean Hokkien slang for "white people". 
Life was a breeze, as long as I kept away from Chinese restaurants and Chinese food at hawker centres - which was no loss to me anyway....

With the influx of Chinese nationals in Singapore, we monolinguals are becoming "foreigners" in our own country. Many businesses are now manned by Chinese nationals and it is next to impossible to make my orders or requests understood. Nowadays, I just avoid all businesses where the person at the counter is a Chinese national - there is no point wasting my breath and time on them.... However, our own citizens are now breaking into Mandarin at every opportunity they get. Go to a bank and when you reach the counter, you are greeted with a barrage of Mandarin. Don't they know that English is still the official business language? This also happens at government departments. The alternative is to move to a Western country... At worst, we might have to pack up and go too.

While some English-speaking Chinese Singaporeans recognise the newfound economic value of the Chinese language and may want their children to learn it, others will remain repelled by the Chinese language and feel greater cultural affinity with Westerners.

\section{Singapore's efforts to build a distinctive national identity}

In 2019, Singapore launched the Bicentennial, a year-long commemoration of the founding of Singapore as a British trading post in 1819 as well as seven hundred years of Singapore's history since the 1300s. The Bicentennial's slogan, "From Singapore to Singaporean," reflects its mission to celebrate a national identity that emerged from a long and rich history (SG Bicentennial 2019).

The Singapore government has also adopted a policy of vigilantly emphasising the distinctiveness of the Singaporean national identity. In September 2014, Singapore responded to China's building of the China Cultural Centre in Singaporewhich cost 44 million Singapore dollars-by establishing the much larger Singapore Chinese Cultural Centre (SCCC) building, which cost 110 million Singapore dollars and was completed in May 2017. The message was crystal clear: Singapore's Chinese culture is distinct from that of China. In January 2016, a multimedia exhibition, titled "Blooms of Vitality, Colours of Life," was organised by the SCCC to promote exactly this message, that the culture of Chinese Singaporeans is unique (Leong 2016).

On September 6, 2018, at the 95th anniversary of Singapore's biggest Chineselanguage newspaper, Lianhe Zaobao, Prime Minister Lee Hsien Loong stressed that Chinese Singaporean culture is "unique, and not just a copy of another country's culture and heritage." He also praised Zaobao's promotion of Singapore's unique Chinese culture and objective reporting uninfluenced by China (Lee 2018). On February 4, 2019, Prime Minister Lee devoted his Chinese New Year message to illustrating how Chinese Singaporeans "have become distinct from Chinese communities elsewhere." He also encouraged new immigrants to "adjust their social norms to our local context, and embrace our uniquely Singaporean cultural habits" (2019a). 
In his National Day Rally speech in Mandarin on August 18, 2019, Prime Minister Lee explained in detail how "the Chinese Singaporean identity formed gradually over the last 200 years." Although the forefathers of Chinese Singaporeans had arrived "intending to return to China one day" and were "passionate about their homeland," by the 1960s the Chinese in Singapore had "begun to identity themselves as Singapore citizens, and had transferred their loyalties to Singapore" (Lee 2019b).

On September 24, 2019, Lianhe Zaobao's “distinctly Singapore perspective" on China was again stressed by Singaporean Senior Minister Teo Chee Hean, who pointed out that Zaobao differentiates itself from media in Greater China and the West by being "an insider with an outsider's perspective," meaning to be "close enough to feel the pulse inside China, but detached enough to avoid viewing developments from an ideological viewpoint" (Teo 2019).

\section{Conclusion}

Shifts in the cultural identity of an ethnic group often divide the group into those who accept the newly emerged identity, and those who do not. First Wave DeSinicisation segregated early Chinese immigrants in Malaya into creole speakers who acculturated to Chinese-Malayan customs, and those who remained distinctively Chinese. In early twentieth century Singapore, First Wave Re-Sinicisation divided the local-born Chinese into Chinese-speaking patriots of the Chinese Republic, and English-speaking "King's Chinese" who swore allegiance to the British Empire.

Second Wave De-Sinicisation was again divisive both linguistically and in terms of cultural identity. The Singapore Chinese were split into those who identified themselves as Chinese nationals, and those who identified Singapore as home. Amongst Chinese Singaporeans, there was also a distinct rift between the English-speaking and Chinese-speaking. Second Wave Re-Sinicisation, and the attempted integration of new Chinese immigrants into Singapore society, resulted in resentment between Singapore-born Chinese and new Chinese immigrants.

With an ascendant China joining America in the great game of global influence, a third wave of re-Sinicisation may yet again descend upon the Singaporeborn Chinese. Regardless of political loyalties, some Chinese Singaporeans, born to de-Sinicised, monolingual parents, may seek to rediscover their Chinese origins, in "an effort to define their own personal, social and national identities in a way that enhances their sense of self-esteem in a world where their immediate ancestors had subconsciously accepted that they were lesser beings in a Western universe" (Mahbubani 2009, p. 38). Amidst the great game of the two superpowers, Singapore's continued existence as a distinct nation rests on a delicate balancing act: promoting English without becoming a pseudo-Western society, while, for its ethnic Chinese citizens, promoting Mandarin without becoming indistinct from China. 
Acknowledgements This article benefitted immensely from the meticulous comments of Distinguished Professor Nicholas Koss, OSB (Peking University).

Funding Not applicable.

\section{Declarations}

Conflict of interest I declare that there is no conflict of interest in the publication of this article.

Ethical approval I hereby declare that this manuscript is the result of my independent creation under the reviewer's comments. Except for the quoted contents, this manuscript does not contain any research achievements that have been published or written by other individuals or groups.

Author contributions Ashton $\mathrm{Ng}$ is the sole author of this manuscript.

Open Access This article is licensed under a Creative Commons Attribution 4.0 International License, which permits use, sharing, adaptation, distribution and reproduction in any medium or format, as long as you give appropriate credit to the original author(s) and the source, provide a link to the Creative Commons licence, and indicate if changes were made. The images or other third party material in this article are included in the article's Creative Commons licence, unless indicated otherwise in a credit line to the material. If material is not included in the article's Creative Commons licence and your intended use is not permitted by statutory regulation or exceeds the permitted use, you will need to obtain permission directly from the copyright holder. To view a copy of this licence, visit http://creativecommons.org/licen ses/by/4.0/.

\section{References}

Chan, M. 2016. How Singapore's military vehicles became Beijing's diplomatic weapon. Retrieved July 19, 2019 from https://www.scmp.com/week-asia/politics/article/2051322/how-singapores-militaryvehicles-became-beijings-diplomatic.

Goh, C.T. 2001. National Day Rally 2001 Speech. Singapore Government Press Release. Retrieved February 5, 2019 from https://www.nas.gov.sg/archivesonline/data/pdfdoc/2001081903.htm.

Hsiao, R. 2019. A Preliminary Survey of CCP Influence Operations in Singapore. China Brief, 19 (13). Retrieved July 16, 2019 from https://jamestown.org/program/a-preliminary-survey-of-ccpinfluence-operations-in-singapore/.

Huang, J. 2019. The Sun Yat Sen Nanyang Memorial Hall and the Chinese Community of Singapore: History, Repositioning and Contestation. In A General History of the Chinese in Singapore, ed. C.G. Kwa and B.L. Kua, 819-846. Singapore: World Scientific.

Jaipragas, B. 2017. Hong Kong to return seized armoured vehicles to Singapore. Retrieved July 19, 2019 from https://www.scmp.com/week-asia/geopolitics/article/2065027/hong-kong-return-singaporesseized-armoured-vehicles.

Jayakumar, S. 2016. The four Rs behind the unhappiness. Straits Times. Retrieved October 6, 2016 from https://www.straitstimes.com/opinion/the-four-rs-behind-the-unhappiness.

Johnson, I. 2017. In Singapore, Chinese Dialects Revive After Decades of Restrictions. New York Times. Retrieved August 26, 2017 from https://www.nytimes.com/2017/08/26/world/asia/singa pore-language-hokkien-mandarin.html.

Kwa, C.G., and B.L. Kua, eds. 2019. A General History of the Chinese in Singapore. Singapore: World Scientific.

Lai, L. 2019. National Day Rally 2019: How the Chinese Singaporean identity has evolved in 200 years. Straits Times. Retrieved October 1, 2019 from https://www.straitstimes.com/politics/natio nal-day-rally-2019-how-chinese-singaporean-identity-has-evolved-in-200-years.

Lee, K.Y. 1998. The Singapore Story: Memoirs of Lee Kuan Yew. Singapore: Times Editions. 
Lee, G. 2011a. My 10-Year Nightmare. In My Lifelong Challenge: Singapore's Bilingual Journey, 296-299. Singapore: Straits Times Press.

Lee, K.Y. 2011b. My Lifelong Challenge: Singapore's Bilingual Journey. Singapore: Straits Times Press.

Lee, H.L. 2018. PM Lee Hsien Loong at Lianhe Zaobao's 95th Anniversary Gala Dinner. Prime Minister's Office Singapore. Retrieved September 6, 2018 from https:/www.pmo.gov.sg/Newsroom/ pm-lee-hsien-loong-lianhe-zaobaos-95th-anniversary-gala-dinner.

Lee, H.L. 2019a. Chinese New Year Message 2019. Prime Minister's Office Singapore. Retrieved February 5, 2019 from https://www.pmo.gov.sg/Newsroom/Chinese-New-Year-Messa ge-2019-by-PM-Lee-Hsien-Loong.

Lee, H.L. 2019b. National Day Rally 2019 (Chinese). Prime Minister's Office Singapore. Retrieved August 18, 2019 from https://www.pmo.gov.sg/Newsroom/National-Day-Rally-2019-speechChinese.

Leong, W.K. 2015. The Evolution of the Chinese Language. In 50 Years of the Chinese Community in Singapore, ed. C.L. Pang, 131-148. Singapore: World Scientific.

Leong, W.K. 2016. Why is Republic's Chinese culture unique? Straits Times. Retrieved January 9, 2016 from https://www.straitstimes.com/singapore/why-is-republics-chinese-culture-unique.

Lim, B.K. 1917. The Chinese in Malaya. In Present-Day Impressions of the Far East and Prominent and Progressive Chinese at Home and Abroad, ed. W. Feldwick, 875-882. London: Globe Encyclopedia Company.

Lim, D. 2017. Nathan Hartono Performs in School Visits as New Chinese Language Ambassador. Straits Times. Retrieved January 9, 2017 from https://www.straitstimes.com/singapore/educa tion/nathan-hartono-performs-in-school-visits-as-new-chinese-language-ambassador.

Lim, R. 2011. Chinese Inside. In My Lifelong Challenge: Singapore's Bilingual Journey, 310-314. Singapore: Straits Times Press.

Lim, L., and M. Mathews. 2017. Emerging Sense of Singaporean Identity Independent of Ethnic Heritage. Straits Times. Retrieved November 15, 2017 from http://www.straitstimes.com/opinion/ emerging-sense-of-sporean-identity-independent-of-ethnic-heritage.

Mahbubani, K. 2009. Can Asians Think? Singapore: Marshall Cavendish Editions.

Mahbubani, K. 2015. Can Singapore Survive. Singapore: Straits Times Press.

Ng, A. 2019a. China's Rise and the Re-Sinicization of Ethnic Chinese in Singapore. St Antony's International Review 14 (2): 170-189.

Ng, F.B. 2019b. Peranakan Community and Culture. In A General History of the Chinese in Singapore, ed. C.G. Kwa and B.K. Kua. Singapore: World Scientific.

Ng, W.M. 2019c. US think tank accuses the CCP of influencing public opinion in Singapore through Chinese associations: Singapore Chinese Chamber of Commerce \& Industry and the Singapore Federation of Chinese Clan Associations refute claims. Lianhe Zaobao. Retrieved July 19, 2019 from https://www.zaobao.com.sg/znews/singapore/story20190719-973663.

Pang, C.L. 2015. Singapore Federation of Chinese Clan Associations: Revitalising Clan Associations". In 50 Years of the Chinese Community in Singapore, ed. C.L. Pang, 29-50. Singapore: World Scientific.

Perry, J.C. 2017. Singapore: Unlikely Power. New York: Oxford University Press.

Population.sg. 2016. Singapore's Immigrant Associations - Inclusive or exclusive? Population.sg. Retrieved August 3, 2016 from https://www.population.sg/articles/singapores-immigrant-assoc iations--inclusive-or-exclusive.

Reimers, F.M. 2017. Foreword. In Lee Kuan Yew's Educational Legacy, ed. S.T. Oon, L.L. Ee, and D. Hung. Singapore: Springer.

Saw, S.H. 1999. The Population of Singapore. Singapore: Institute of Southeast Asian Studies.

SG Bicentennial. About the Singapore Bicentennial. SG Bicentennial. Retrieved September 18, 2019 from https://www.bicentennial.sg/about/.

Song, O.S. 2016. One Hundred Years' History of the Chinese in Singapore: The Annotated Version. Singapore: National Library Board.

Straits Times. 2018. Panel on what makes a Chinese Singaporean. Straits Times. Retrieved May 19, 2018 from https://www.straitstimes.com/singapore/panel-on-what-makes-a-chinese-sporean.

Straits Times. 2019. Chinese embassy responds to report on influence operations in Singapore. Straits Times. Retrieved July 19, 2019 from https://www.straitstimes.com/singapore/chinese-embassyresponds-to-report-on-influence-operations-in-singapore. 
Tan, H. 2017. Chinese media attacks 'hysterical paranoia' of countries worried about Beijing's influence. CNBC. Retrieved December 13, 2017 from https://www.cnbc.com/2017/12/13/sam-dastyari-peopl es-daily-press-slams-western-paranoia.html.

Teo, C.H. 2019. SM Teo Chee Hean at the launch of ThinkChina." Prime Minister's Office Singapore. Retrieved September 24, 2019 from https://www.pmo.gov.sg/Newsroom/ SM-Teo-Chee-Hean-at-launch-of-Think-China.

Wang, G. 2018. Nanyang: Essays on Heritage. Singapore: ISEAS-Yusof Ishak Institute.

Xinhua. 2019. U.S. foundation report on so-called China exerting influence on Chinese Singaporeans groundless: Chinese embassy. Xinhua. Retrieved July 19, 2019 from http://www.xinhuanet.com/ english/asiapacific/2019-07/19/c_138241486.htm.

Yuen, S. 2018a. An Evolving Singapore Chinese identity: Journey to the West - and now, the East. Retrieved February 18, 2018 from https://www.straitstimes.com/singapore/journey-to-the-west-andnow-the-east. Straits Times.

Yuen, S. 2018b. 3 Ways in which the Chinese Singaporean Identity is Evolving. Retrieved May 19, 2018 from https://www.straitstimes.com/singapore/3-ways-in-which-the-chinese-singaporean-identity-isevolving. Straits Times.

Yuen, S., and W.M. Ng. 2018a. Being Chinese in Multiracial Singapore: A Framework to Check One's Ignorance. Retrieved February 15, 2018 from https:/www.straitstimes.com/opinion/being-chinesein-multi-racial-spore. Straits Times.

Yuen, S., and W.M. Ng. 2018b. The Chinese Singaporean Identity: A Complex, Ever Changing Relationship. Retrieved May 19, 2018 from https://www.straitstimes.com/opinion/a-complex-ever-changingrelationship. Straits Times.

Zhang, F. 2017. Assessing China's Changing Attitudes Towards Singapore. East Asia Institute Background Brief, 1241. Retrieved April 27, 2017 from http://www.eai.nus.edu.sg/publications/files/ BB1241.pdf.

Zhou, Z. 2015. New Immigrants from China: Boosting Bilateral Relations. In 50 Years of the Chinese Community in Singapore, ed. C.L. Pang, 29-50. Singapore: World Scientific. 